\title{
CEFTA Agreement and Opportunities for Wood Furniture Export of the Republic of Macedonia
}

\section{CEFTA sporazum i mogućnosti izvoza namještaja Republike Makedonije}

\author{
Original scientific paper • Izvorni znanstveni rad \\ Received-prispjelo: 20. 2. 2015. \\ Accepted-prihvaćeno: 29. 1. 2016. \\ UDK: $630 * 79$ \\ doi:10.5552/drind.2016.1513
}

\begin{abstract}
This paper is focused on business possibilities of CEFTA 2006 and its influence on export trend of wood furniture from the Republic of Macedonia. First, six categories of wood furniture export are analyzed such as: office furniture, kitchen furniture, bedroom furniture, living and dining room furniture, shop furniture and other furniture, presenting a positive trend in each category, except for living and dining room furniture. The total export of wood furniture shows a positive trend. The second part presents comparative research using mathematical and statistical methods for determining wood furniture export trends, analyzing the export to different countries and the use of the CEFTA 2006 agreement. The results show a positive trend of export of wood furniture from Macedonia towards CEFTA countries. The main purpose of this research is to provide an overview of the use of the CEFTA 2006 agreement in the field of wood furniture export from the Republic of Macedonia, providing policy and business recommendations for the use of the CEFTA 2006 agreement. Taking into consideration the CEFTA 2006 agreement benefits, CEFTA member countries would become more competitive and prepared towards the European and global market.
\end{abstract}

Key words: CEFTA, wood furniture, export, cooperation, forecasting trends

SAŽETAK • Cilj je ovog rada istražiti poslovne mogućnosti udruženja CEFTA 2006 i njegov utjecaj na izvozne trendove namještaja Republike Makedonije. U prvom dijelu rada analizirane su izvozne vrijednosti šest kategorija namještaja, $i$ to uredskog namještaja, kuhinjskog namještaja, namještaja za spavaće sobe, namještaja za blagovaonice i dnevne sobe, namještaja za trgovine te ostalog namještaja za koji je utvrđen pozitivan trend uvoza. Jednako tako, utvrđen je pozitivan trend vrijednosti ukupnog izvoza namještaja. U drugom dijelu rada, primjenom statističkih i matematičkih metoda, prikazane su analize izvoza namještaja Republike Makedonije i analizirana uporaba CEFTA 2006 sporazuma. Nadalje, rezultati su pokazali zadovoljavajući pozitivan trend makedonskog izvoza namještaja prema zemljama članicama CEFTA-e. Cilj ovog istraživanja bio je dati pregled primjene CEFTA 2006 sporazuma na području izvoza namještaja od drva Republike Makedonije, s naglaskom na primjenu CEFTA 2006 sporazuma. Sporazum CEFTA 2006 donosi zemljama članicama prednosti u obliku postizanja veće konkurentnosti i pripremljenosti za svjetska i europska tržišta.

Ključne riječi: CEFTA, namještaj od drva, izvoz, suradnja, predviđanje trendova

\footnotetext{
Authors are associate professor and assistant professor at University American College Skopje, School of Business Economics and Management, Republic of Macedonia. ${ }^{2}$ Author is professor at University "Ss Cyril and Methodius", Faculty of Design and Technology of Furniture and Interior, Skopje, Republic of Macedonia. ${ }^{3}$ Author is associate professor at University "Ss Cyril and Methodius", Faculty of Economics, Skopje, Republic of Macedonia.

Autori su izvanredna profesorica i docent Sveučilišnoga američkog koledža u Skopju, Škola poslovne ekonomije i menadžmenta, Skopje, Republika Makedonija. ${ }^{2}$ Autorica je profesorica Sveučilišta Sv. Ćiril i Metod, Fakultet dizajna i tehnologije namještaja i interijera, Skopje, Republika Makedonija. ${ }^{3}$ Autor je izvanredni profesor Sveučilišta Sv. Ćiril i Metod, Ekonomski fakultet, Skopje, Republika Makedonija.
} 


\section{INTRODUCTION}

\section{UVOD}

The integration and implementation of the Central European Free Trade Agreement (CEFTA) has been the main activity of foreign trade policy of the Republic of Macedonia in the last decade. The reason for this activity is the expectation that the membership of the Republic of Macedonia in CEFTA will significantly contribute to the continuous efforts for strengthening the regional trade cooperation and increase export as an important step to Euro Atlantic Integration. New CEFTA 2006 provides a much more comprehensive framework for development of mutual economic relations among the countries, especially in wood furniture export. Timber companies must continually strive to improve or at least maintain their market share. Nowadays, consumers are very demanding and they require as much as possible information about the product to be sure about its quality (Oblak and Glavonjić, 2014). Analyzing the current wood furniture export from the Republic of Macedonia towards the CEFTA countries, presents a good base for future research of cooperation with other CEFTA countries and possibilities for further development.

\subsection{The main benefits from CEFTA 2006}

\subsection{Glavne koristi od CEFTA-e 2006}

The Republic of Macedonia was the last country to accede the original CEFTA. The agreement for extending and modernizing CEFTA was signed on 19 December 2006 and the "new" agreement was called CEFTA 2006 for the purpose of terminological differentiation. This modern and comprehensive free trade agreement entered into force on 26 July 2007 for five Parties - Albania, Macedonia, Moldova, Montenegro and UNMIK/Kosovo, while for Croatia it entered into force on 22 August 2007, for Serbia on 24 October 2007 and for Bosnia and Herzegovina on 22 November 2007. Thus, full implementation of CEFTA 2006 started at the end of 2007, according to the official report from the CEFTA web site (http://www.ceftatradeportal.com/, 2014).

CEFTA 2006 consolidates 32 bilateral free trade agreements previously concluded among its signatories, representing an international framework for increased liberalization of trade in goods. The application of CEFTA 2006 is expected to cause a significant increase of trade exchange in the region, which in turn will result in increased competitive advantages. Membership in CEFTA 2006 significantly contributes to the continuous efforts for strengthening the regional economic cooperation, further liberalization of foreign trade exchange, and continuation of activities for harmonization of trade rules with international standards (Mojsovska and Tosheva, 2011). CEFTA 2006 is a result of the efforts for as urgent as possible economic approximation and consolidation of the SEE countries. Such aspirations, on one hand, and the unequal progress of different countries regarding integration in the global economic trends, imposed a need to relax the preconditions for acceding to the agreement. Novelty in CEFTA 2006 is the broadening of the agreement with new trade issues that were not regulated by the original CEFTA. The purpose of introducing new issues was to increase the economic cooperation among the countries/territories in the region, as well as to increase the processes of harmonization of their measures with the international standards according to the CEFTA official web site (http://www.cefta.int/).

One of the main goals of CEFTA2006 is to achieve substantial liberalization of trade among its members (Tosheva and Efremov, 2007). The Agreement provides full elimination of customs duties in the international trade of all signatories and for all industrial products not later than 31 December 2008. From 2009, the trade of furniture in CEFTA countries is without custom protection (Efremov, 2013), which is a unique opportunity for furniture companies in these countries. Another important goal of CEFTA 2006 is to encourage trade and investments by applying equitable, understandable and predictable rules, which would be a beneficial base for creating joint ventures and regional cooperation for joint entrance and export on global market. Therefore, this paper analysis the current use of CEFTA benefits of furniture companies from the Republic of Macedonia in the period 2005 to 2013.

\subsection{Wood industry and production of furniture in the Republic of Macedonia \\ 1.2. Prerada drva i proizvodnja namještaja u Republici Makedoniji}

The Republic of Macedonia is a country with rich tradition in wood processing due to its forests, tradition and professional labor force. The lumber sawmills were among the first industries in our country, and the industry of furniture manufacturing, as continuation of sawmill production process, started to develop in the fifties of the last century. In that period, the major wood-processing plants were established, determined by the program for highly protected market of the former Yugoslavia. According to Glavonjic et al. (2009) and Kitek Kuzman et al. (2012), globalization and the regional cooperation and participation in the global marketplace are a major driver of reforms being implemented in post socialist Yugoslavia. Privatization of all the former plants has been completed, and the private initiative has established many new companies in this sector, in the process of which the companies have to adjust to the market conditions for doing business. Currently, in this industry, there are over five hundred furniture manufacturing companies and around sixty wood-processing companies. However, according to Shumanska (2014), in Macedonia the wood-processing companies are way behind the modern process of manufacturing due to the outdated technology, and this greatly affects the outcome of manufacturing and hence also the demand for these products.

The international trade of furniture from the Republic of Macedonia is limited, as the whole exchange is made with the neighboring countries. According to Meloska et al. (2011), the reasons for limited international trade mainly lies in small transportation costs, joint market of the former Yugoslavia and also the good 
knowledge of neighboring markets and already established relationships. Also, the import to the Republic of Macedonia, analyzed in the same paper of Meloska et al. (2011), shows that the same neighboring countries are the main importing countries for wood furniture, too.

Wood furniture manufacturers in Macedonia should undertake several actions towards expanding towards global market. Above all, a serious research of furniture market should be made. The market offer should not to be individual, but made through associations and groups, with strong promotional activities (Meloska et al., 2011). CEFTA 2006 supports the regional cooperation; therefore, it is necessary to analyze the current wood furniture export from the Republic of Macedonia towards the CEFTA countries. This is the starting analysis for a further and deeper analysis of export strategies of all CEFTA countries, aimed at establishing how they can benefit from the CEFTA 2006 agreement.

\section{METHODS AND MATERIAL} 2. METODE I MATERIJALI

The aim of this paper was to analyze the export trends of wood furniture from the Republic of Macedonia, with the focus on CEFTA countries (old CEFTA countries as Croatia, Slovenia, Bulgaria and Romania and CEFTA 2006 countries - Albania, Bosnia and Herzegovina, Kosovo, Macedonia, Montenegro, Moldova, and Serbia). The research methodology was quantitative and used the preliminary export data from the State Statistical Office of the Republic of Macedonia for the period 2005 to 2013 with custom tariff numbers converted into Standard International Trade Classification (SITC) and also data from Macedonian Chamber of Commerce.
The analyses were done of the export presented in EUR, using mathematical and statistical methods, with graphics in Excel Microsoft Office. For analyzing the macroeconomic export trends of the Republic of Macedonia, dynamic economic analysis of time series data was performed, using one of the time series models presented in the research of Oblak et al. (2012).

\section{RESULTS AND DISCUSSION}

\section{REZULTATI I RASPRAVA}

\subsection{Wood furniture export from Republic of Macedonia to CEFTA 2006 countries}

3.1. Izvoz namještaja Republike Makedonije u zemlje CEFTA 2006

According to the preliminary export data from the State Statistical Office of the Republic of Macedonia for the period 2005 to 2013, in the period 2005 to 2008 , the total export of wood furniture from the Republic of Macedonia shows a trend of continuous increase up to 2008, presented with a linear trend line in Graph 1. In 2009 and 2010, there is a decrease of about 15 and 21 percent, respectively, compared to the previous year. After 2011, there is an increasing trend until 2013 of about 4-6 percent per year compaed to the previous year. The linear trend line of the total wood furniture export is increasing, but however, the regression $R^{2}=0.260$ is not high enough to present clear dependence of the export amount during the years, and therefore it is not easy to predict and forecast.

In Table 1, it is important to stress the share of different types of wood in the total export of wood furniture. The shop, office and kitchen furniture covers just a small share of 2.97 percent, 4.02 percent and 6.84 percent from the total export of wood furniture, which presents an opportunity for increase in the future.

Table 1 Export of wood furniture by category from the Republic of Macedonia in the period 2005 to 2013

Tablica 1. Izvoz namještaja prema kategorijama proizvoda Republike Makedonije u razdoblju od 2005. do 2013.

\begin{tabular}{|l|c|c|c|c|c|c|c|}
\hline & $\begin{array}{c}\text { Office } \\
\text { furniture } \\
\text { Uredski } \\
\text { namještaj }\end{array}$ & $\begin{array}{c}\text { Kitchen } \\
\text { furniture } \\
\text { Kuhinjski } \\
\text { namještaj }\end{array}$ & $\begin{array}{c}\text { Bedroom } \\
\text { furniture } \\
\text { Namještaj za } \\
\text { spavaće sobe }\end{array}$ & $\begin{array}{c}\text { Living\& Dining } \\
\text { furniture } \\
\text { Namještaj za } \\
\text { dnevne sobe } i \\
\text { blagovaonice }\end{array}$ & $\begin{array}{c}\text { Shop } \\
\text { furniture } \\
\text { Namještaj } \\
\text { za trgovine }\end{array}$ & $\begin{array}{c}\text { Other } \\
\text { furniture } \\
\text { Ostali } \\
\text { namještaj }\end{array}$ & $\begin{array}{c}\text { Total } \\
\text { export } \\
\text { Ukupni } \\
\text { izvoz }\end{array}$ \\
\hline 2005 & EUR & EUR & EUR & EUR & EUR & EUR & EUR \\
\hline 2006 & 47.828 & 136.277 & 778.006 & 1.820 .132 & 20.816 & 218.516 & 3.021 .574 \\
\hline 2007 & 132.224 & 156.145 & 879.077 & 3.782 .205 & 554.468 & 793.703 & 6.297 .821 \\
\hline 2008 & 317.374 & 270.795 & 1.323 .448 & 5.735 .642 & 179.645 & 636.733 & 8.463 .638 \\
\hline 2009 & 290.192 & 504.624 & 1.819 .974 & 3.920 .803 & 21.640 & 659.863 & 7.217 .096 \\
\hline 2010 & 347.123 & 671.555 & 2.280 .988 & 1.648 .250 & 69.978 & 689.734 & 5.707 .629 \\
\hline 2011 & 179.864 & 540.787 & 2.419 .134 & 1.373 .211 & 136.661 & 1.371 .588 & 6.021 .245 \\
\hline 2012 & 387.668 & 632.679 & 2.967 .467 & 732.830 & 400.610 & 1.321 .376 & 6.442 .629 \\
\hline 2013 & 399.476 & 723.188 & 3.441 .278 & 548.342 & 206.277 & 1.383 .095 & 6.701 .657 \\
\hline $\begin{array}{l}\text { Total EUR } \\
\text { Ukupno EUR }\end{array}$ & 2.181 .954 & 3.709 .354 & 16.925 .533 & 22.456 .525 & 1.611 .426 & 7.350 .128 & 54.234 .920 \\
\hline$\%$ & 4.02 & 6.84 & 31.21 & 41.41 & 2.97 & 13.55 & 100.00 \\
\hline Mean & 242.439 & 412.150 & 1.880 .615 & 2.495 .169 & 179.047 & 816.681 & 6.026 .102 \\
\hline Std Dev & 134.565 & 253.527 & 958.347 & 1.720 .364 & 186.800 & 448.294 & 1.579 .669 \\
\hline Coef Var & $56 \%$ & $62 \%$ & $51 \%$ & $69 \%$ & $104 \%$ & $55 \%$ & $26 \%$ \\
\hline AROC & $30 \%$ & $23 \%$ & $20 \%$ & $-14 \%$ & $33 \%$ & $26 \%$ & $10 \%$ \\
\hline$r$ (Corr.) & 0.8324 & 0.9354 & 0.9785 & -0.5433 & 0.2283 & 0.9168 & 0.5101 \\
\hline
\end{tabular}




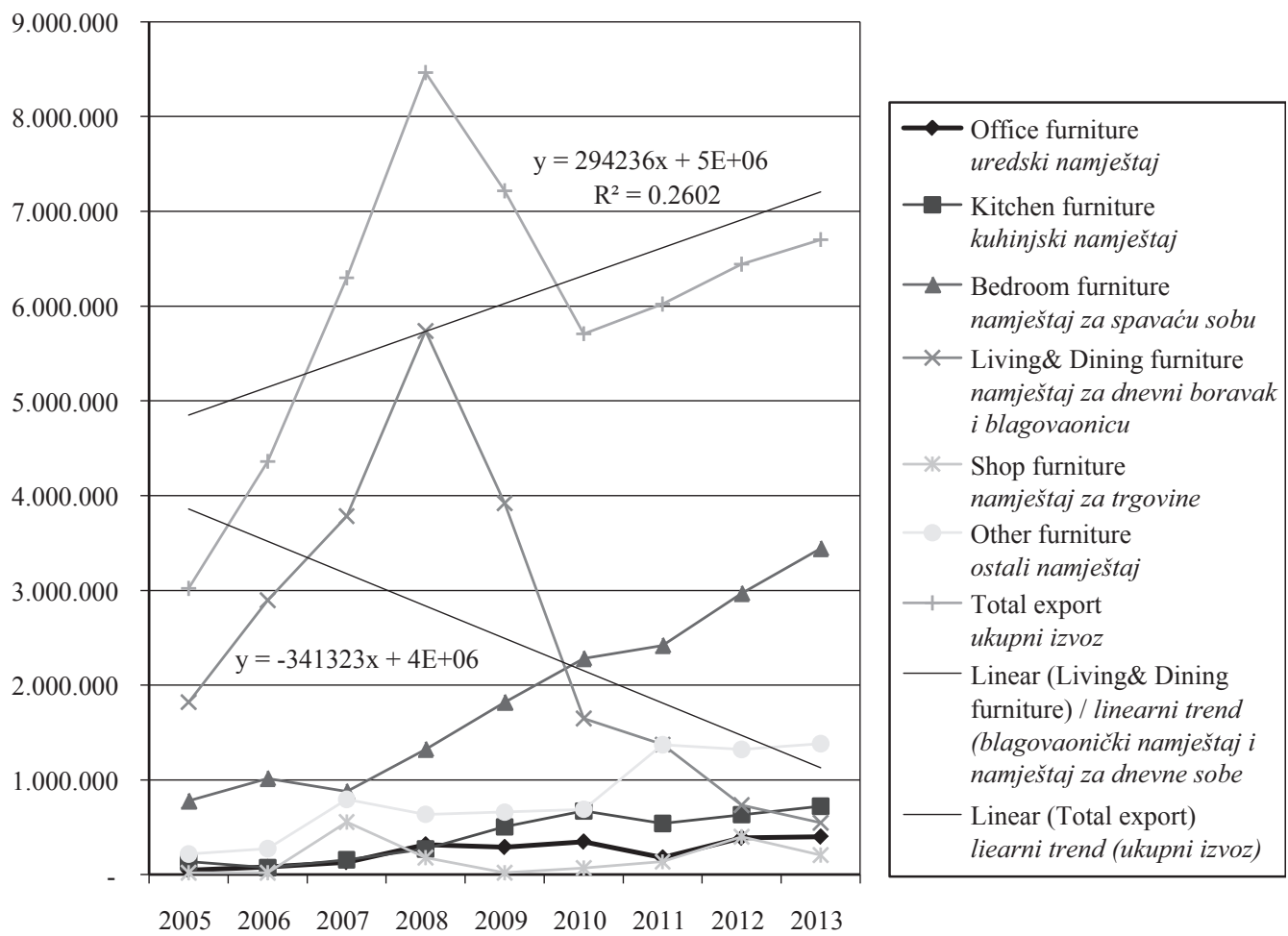

Figure 1 Export of wood furniture from the Republic of Macedonia in the period 2005 to 2013

Slika 1. Izvoz namještaja Republike Makedonije u razdoblju od 2005. do 2013.

When analyzing the export of different types of wood furniture presented in Table 1, comparing 2005 with 2013, increasing trends can be observed for all categories of wood furniture except for export of living and dining furniture, where there is a negative trend with negative AROC (average rate of change) (-14\%). This is the only category with lowering trend line presented in Graph 1. The other categories have a positive AROC: it is the highest for shop furniture (33\%), followed by office furniture $(30 \%)$, other furniture ( 26 $\%)$, kitchen furniture (23\%) and bedroom furniture (20 $\%)$. This results in a positive trend line of wood furniture export from Macedonia.

Further, the analysis is given of the export from the Republic of Macedonia for each category of wood furniture as follows: office furniture, kitchen furniture, bedroom furniture, living and dining furniture, shop furniture and other furniture.

\subsection{Export of office wood furniture from Macedonia}

3.2. Izvoz uredskog namještaja Republike Makedonije

Table 2 presents the export of office wood furniture in the period 2005 to 2013 to the ten main countries. Among the ten most important export markets, six are members of CEFTA or CEFTA 2006 (Croatia, Bosnia and Herzegovina, Kosovo, Serbia, Montenegro and Romania) and four are European countries (Holland, Germany, Greece and Switzerland). Holland holds the first place with the total export of EUR 544.745 , but only in the last three years. The analysis of the export to CEFTA/CEFTA 2006 countries shows that there is a variable trend of export in different years, participating with 64 percent in the total export, mean-
Table 2 Export of office furniture from the Republic of Macedonia to main 10 export countries in the period 2005 $-2013$

Tablica 2. Izvoz uredskog namještaja Republike Makedonije u deset najznačajnijih zemalja izvoznica u razdoblju od 2005. do 2013.

\begin{tabular}{|l|c|}
\hline $\begin{array}{l}\text { Countries } \\
\text { Države }\end{array}$ & $\begin{array}{c}\text { Export in EUR } \\
\text { Izvoz u EUR }\end{array}$ \\
\hline Netherlands / Nizozemska & 544.745 \\
\hline Croatia/ Hrvatska & 408.126 \\
\hline $\begin{array}{l}\text { Bosnia\&Herzegovina } \\
\text { Bosna i Hercegovina }\end{array}$ & 346.219 \\
\hline Kosovo/ Kosovo & 275.834 \\
\hline Serbia+MN/ Srbija + Crna Gora ${ }^{I}$ & 235.204 \\
\hline Germany/ Njemačka & 75.399 \\
\hline Greece/ Grčka & 65.483 \\
\hline Montenegro/ Crna Gora & 39.600 \\
\hline Switzerland/ Švicarska & 36.610 \\
\hline Romania/ Rumunjska & 35.075 \\
\hline Other countries/ Ostale zemlje & 119.660 \\
\hline Total EUR/ Ukupno EUR & $\mathbf{2 . 1 8 1 . 9 5 4}$ \\
\hline
\end{tabular}

ing that these countries are important market for future increase of export of Macedonian office wood furniture (Graph 2).

\footnotetext{
In 2003, Serbia and Montenegro were reconstituted as a state union officially known as the State Union of Serbia and Montenegro, transitioning to two independent nations by 2006. In the period 2005-2006, the State Statistical Office of the Republic of Macedonia had collected joint preliminary data for Serbia and Montenegro, and from 2007 preliminary data was separated for Serbia and Montenegro as different states.
} 
non CEFTA countries

zemlje izvan CEFTA-e;

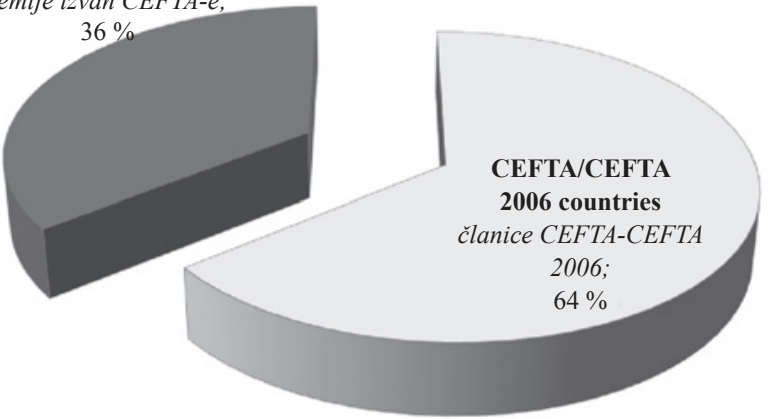

Figure 2 Macedonian export of office wood furniture to CEFTA and non CEFTA countries in the period 2005 - 2013 Slika 2. Makedonski izvoz uredskog namještaja u članice CEFTA-e i zemlje izvan CEFTA-e u razdoblju od 2005. do 2013.

\subsection{Export of kitchen wood furniture from} Macedonia

3.3. Izvoz kuhinjskog namještaja Republike Makedonije

Table 3 presents the export of kitchen wood furniture in the period 2005 to 2013 to the ten main coun-

Table 3 Export of kitchen furniture from the Republic of Macedonia to main 10 countries

Tablica 3. Izvoz kuhinjskog namještaja Republike Makedonije u deset najznačajnijih zemalja

\begin{tabular}{|l|c|}
\hline Country/ Države & $\begin{array}{c}\text { Export in EUR } \\
\text { Izvoz u EUR }\end{array}$ \\
\hline Croatia/ Hrvatska & 1.399 .486 \\
\hline Slovenia/ Slovenija & 791.706 \\
\hline Serbia+MN/ Srbija + Crna Gora & 335.670 \\
\hline Switzerland/ Švicarska & 327.890 \\
\hline Greece/ Grčka & 201.352 \\
\hline Germany/ Njemačka & 156.511 \\
\hline Montenegro/ Crna Gora & 101.155 \\
\hline Kosovo/ Kosovo & 91.179 \\
\hline $\begin{array}{l}\text { Bosnia\&Herzegovina } \\
\text { Bosna i Hercegovina }\end{array}$ & 89.554 \\
\hline Sweden/ Švedska & 61.805 \\
\hline Other countries/ Ostale zemlje & 153.046 \\
\hline Total EUR/ Ukupno EUR & $\mathbf{3 . 7 0 9 . 3 5 4}$ \\
\hline
\end{tabular}

non CEFTA countries zemlje izvan CEFTA-e;

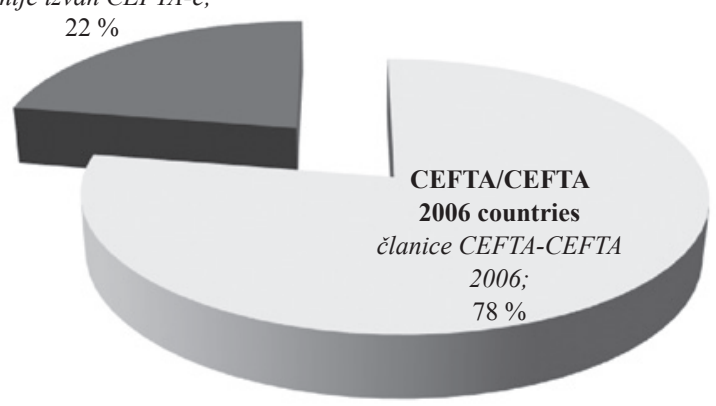

Figure 3 Export of kitchen furniture from the Republic of Macedonia to CEFTA and non-CEFTA countries in the period $2005-2013$

Slika 3. Izvoz kuhinjskog namještaja Republike Makedonije u zemlje članice CEFTA-e i zemlje izvan CEFTA-e u razdoblju od 2005. do 2013. tries. When comparing the ten most important export markets, again six are members of CEFTA or CEFTA 2006 and four are European countries (Switzerland, Greece, Germany and Sweden). CEFTA/CEFTA 2006 countries (Croatia, Slovenia and Serbia) hold the first three places with a total export of about EUR 2.527.000. The CEFTA/CEFTA 2006 countries show a variable trend of export in different years, but they participate with a 78 percent in the total export and they are important market for future increase of export of Macedonian kitchen wood furniture (Graph 3).

\subsection{Export of bedroom wood furniture from Macedonia}

3.4. Izvoz namještaja za spavaće sobe iz Republike Makedonije

Table 4 presents the export of bedroom wood furniture in the period 2005 to 2013 to the ten most important countries. The analysis of the ten most important export markets shows that seven are members of CEFTA or CEFTA 2006 and three are European coun-

Table 4 Export of bedroom furniture from the Republic of Macedonia to the main 10 countries in the period $2005-$ 2013

Tablica 4. Izvoz namještaja za spavaće sobe iz Republike Makedonije u deset zemalja u razdoblju od 2005. do 2013.

\begin{tabular}{|l|c|}
\hline Countries/ Države & $\begin{array}{c}\text { Export in EUR } \\
\text { Izvoz u EUR }\end{array}$ \\
\hline Serbia+MN/ Srbija + Crna Gora & 5.296 .161 \\
\hline Kosovo/ Kosovo & 4.505 .783 \\
\hline Croatia/ Hrvatska & 2.961 .108 \\
\hline $\begin{array}{l}\text { Bosnia\&Herzegovina } \\
\text { Bosna i Hercegovina }\end{array}$ & 1.110 .687 \\
\hline Slovenia/ Slovenija & 961.489 \\
\hline Greece/ Grčka & 715.794 \\
\hline Norway/ Norveška & 330.637 \\
\hline Bulgaria/ Bugarska & 269.351 \\
\hline Germany/ Njemačka & 205.094 \\
\hline Albania/ Albanija & 165.771 \\
\hline Other countries/ Ostale države & 403.657 \\
\hline Total EUR/ Ukupno EUR & 16.925 .533 \\
\hline
\end{tabular}

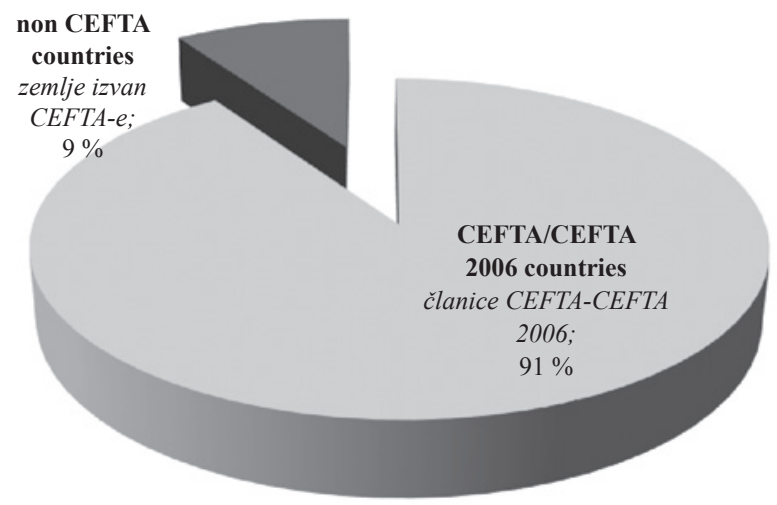

Figure 4 Export of bedroom furniture from the Republic of Macedonia to CEFTA and non CEFTA countries in the period $2005-2013$

Slika 4. Izvoz namještaja za spavaće sobe iz Republike Makedonije u zemlje članice CEFTA-e i zemlje izvan CEFTA-e 
tries (Greece, Norway and Germany). CEFTA/CEFTA 2006 countries (Serbia, Kosovo, Croatia, Bosnia and Herzegovina and Slovenia) hold the first five places with a total export of about EUR 14.835.000. The CEFTA/CEFTA 2006 countries show a variable export trend in different years, but they participate with a 91 percent in the total export and hence they are important market for future increase of export of Macedonian bedroom wood furniture (Graph 4).

\subsection{Export of dining and living room wood} furniture from the Republic of Macedonia

3.5. Izvoz blagovaoničkog namještaja i namještaja za dnevne sobe Republike Makedonije

Table 5 presents the export of dining and living room wood furniture in the period 2005 to 2013 to the ten most important countries. When comparing the ten most important export markets, seven are members of CEFTA or CEFTA 2006 and three are European countries (Greece, Holland and Germany). Croatia holds the first place with a total export of about EUR 7.730.446. The CEFTA/CEFTA 2006 countries show a variable export trend in different years, but they participate with a

Table 5 Export of dining and living room furniture from the Republic of Macedonia to the 10 main countries in the period $2005-2013$

Tablica 5. Izvoz blagovaoničkog namještaja i namještaja za dnevne sobe Republike Makedonije u deset najznačajnijih zemalja u razdoblju od 2005. do 2013.

\begin{tabular}{|l|c|}
\hline Countries/ Zemlje & $\begin{array}{c}\text { Total EUR } \\
\text { Ukupno EUR }\end{array}$ \\
\hline Croatia / Hrvatska & 7.730 .446 \\
\hline Greece / Grčka & 5.329 .133 \\
\hline Serbia+MN / Srbija + Crna Gora & 2.929 .847 \\
\hline Slovenia / Slovenija & 2.830 .155 \\
\hline Montenegro / Crna Gora & 603.204 \\
\hline $\begin{array}{l}\text { Bosnia\&Herzegovina } \\
\text { Bosna i Hercegovina }\end{array}$ & 543.544 \\
\hline Kosovo / Kosovo & 513.621 \\
\hline Bulgaria / Bugarska & 444.125 \\
\hline Netherlands / Nizozemska & 377.703 \\
\hline Germany / Njemačka & 293.442 \\
\hline Other countries / Ostale zemlje & 804.637 \\
\hline Total EUR / Ukupno EUR & $\mathbf{2 2 . 3 9 9 . 8 5 7}$ \\
\hline
\end{tabular}

non CEFTA countries

zemlje izvan CEFTA-e;

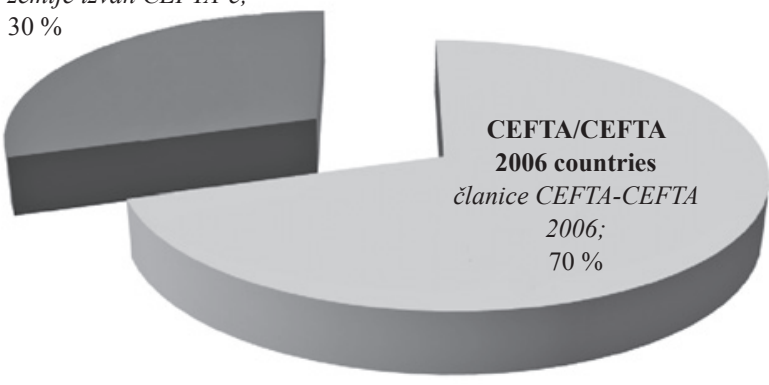

Figure 5 Export of dining and living room furniture from the Republic of Macedonia to CEFTA and non CEFTA countries in the period $2005-2013$

Slika 5. Izvoz blagovaoničkog namještaja i namještaja za dnevne sobe Republike Makedonije u zemlje članice CEFTA-e i zemlje izvan CEFTA-e u razdoblju od 2005. do 2013.
Table 6 Export of shop furniture from the Republic of Macedonia to the 10 main countries in the period 2005 2013

Table 6. Izvoz namještaja za trgovine Republike Makedonije u deset najznačajnijih zemalja u razdoblju od 2005. do 2013.

\begin{tabular}{|l|c|}
\hline Country/ Država & $\begin{array}{c}\text { Total EUR } \\
\text { Ukupno EUR }\end{array}$ \\
\hline Serbia+MN / Srbija + Crna Gora & 500.000 \\
\hline Germany / Njemačka & 326.797 \\
\hline Italy / Italija & 326.115 \\
\hline Kosovo / Kosovo & 160.468 \\
\hline Greece / Grčka & 64.378 \\
\hline UAE / UAE & 60.514 \\
\hline Albania / Albanija & 43.941 \\
\hline Montenegro / Crna Gora & 26.085 \\
\hline Slovenia / Slovenija & 22.563 \\
\hline Croatia / Hrvatska & 14.082 \\
\hline Other countries / Ostale zemlje & 66.485 \\
\hline Total EUR / Ukupno EUR & $\mathbf{1 . 6 1 1 . 4 2 6}$ \\
\hline
\end{tabular}
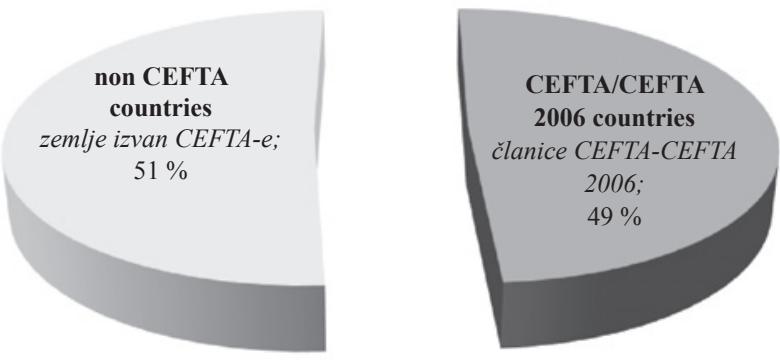

Figure 6 Export of shop furniture from the Republic of Macedonia to CEFTA and non CEFTA countries in the period $2005-2013$

Slika 6. Izvoz namještaja za trgovine Republike Makedonije u zemlje članice CEFTA-e i zemlje izvan CEFTA-e

70 percent in the total export and they are important market for future increase of export of Macedonian dining and living room wood furniture (Graph 5).

\subsection{Export of shop wood furniture from the Republic of Macedonia}

3.6. Izvoz namještaja za trgovine Republike Makedonije

Table 6 presents the export of shop wood furniture in the period 2005 to 2013 to the ten most important countries. When comparing the ten most important export markets, six are members of CEFTA or CEFTA 2006, three are European countries (Germany, Italy and Greece) and one is from the Middle East (UAE). Serbia holds the first place with a total export of about EUR 500.000. CEFTA/CEFTA 2006 countries show a variable export trend in different years, but they participate with a 49 percent in the total export and they are important market for future increase of export of Macedonian shop wood furniture (Graph 6).

\subsection{Export of other furniture from the Republic of Macedonia}

3.7. Izvoz ostalog namještaja Republike Makedonije

Table 7 presents the export of other wood furniture in the period 2005 to 2013 to the ten main coun- 
Table 7 Other furniture export from Republic of Macedonia to main 10 export countries in the period $2005-2013$ Tablica 7. Izvoz ostalog namještaja Republike Makedonije u deset najznačajnijih zemalja izvoznica u razdoblju od 2005. do 2013.

\begin{tabular}{|l|c|}
\hline Country/ Zemlja & $\begin{array}{c}\text { Total EUR } \\
\text { Ukupno EUR }\end{array}$ \\
\hline Kosovo/ Kosovo & 1.038 .426 \\
\hline Serbia+MN/ Srbija + Crna Gora & 961.319 \\
\hline Slovenia/ Slovenija & 857.182 \\
\hline Germany/ Njemačka & 734.953 \\
\hline Croatia/ Hrvatska & 618.749 \\
\hline Greece/ Grčka & 587.678 \\
\hline Norway/ Norveška & 471.623 \\
\hline Montenegro/ Crna Gora & 469.482 \\
\hline Netherlands/ Nizozemska & 392.258 \\
\hline $\begin{array}{l}\text { Bosnia\&Herzegovina } \\
\text { Bosna i Hercegovina }\end{array}$ & 215.667 \\
\hline Other countries/ Ostale zemlje & 1.002 .792 \\
\hline Total EUR/ Ukupno EUR & $\mathbf{7 . 3 5 0 . 1 2 8}$ \\
\hline
\end{tabular}

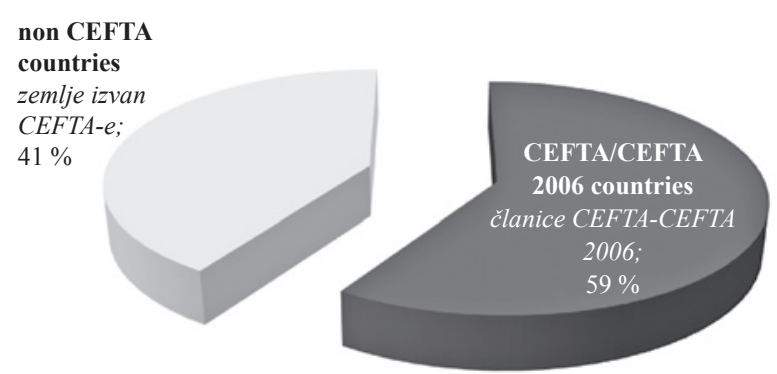

Figure 7 Export of other furniture from the Republic of Macedonia to CEFTA and non CEFTA countries in the period $2005-2013$

Slika 7. Izvoz ostalog namještaja Republike Makedonije u zemlje članice CEFTA-e i zemlje izvan CEFTA-e tries. When comparing the ten most important export markets, six are members of CEFTA or CEFTA 2006 and four are European countries (Germany, Greece, Norway and Holland). CEFTA/CEFTA 2006 countries (Kosovo, Serbia and Slovenia) hold the first three places with a total export of about EUR 2.857.000. The CEFTA/CEFTA 2006 countries show a variable export trend in different years, but they participate with a 59 percent in the total export and they are important market for future increase of export of Macedonian other wood furniture (Graph 7).

The above analysis shows clearly which product categories are the most exported to CEFTA countries and which category of wood furniture is the most exported to CEFTA countries.

\subsection{Export of wood furniture to CEFTA and other countries}

3.8. Izvoz namještaja u zemlje članice CEFTA-e i ostale zemlje

Descriptive statistics (means and standard deviations, coefficients of variations and average rate of change in percentage) were determined for annual export of wood furniture from the Republic of Macedonia for the period $2005-2013$. The results are given in Table 8 .

According to the data shown in Table 8 for the analyzed period 2005 to 2013 , the CEFTA countries are the strategic markets for the export of wood furniture with the total export of about EUR 39.098.000 and a share of 75 percent in the total export. Of the first four countries, three are CEFTA countries that cover the export of Macedonian furniture (Table 8). Croatia holds the first place with the highest export of about 24 percent of the total export, followed by Ser-

Table 8 Descriptive statistics for the total export to main countries from the Republic of Macedonia in the period 2005 - 2013

Tablica 8. Deskriptivna statistika ukupnog izvoza Repubike Makedonije u najznačajnije zemlje u razdoblju od 2005. do 2013.

\begin{tabular}{|c|c|c|c|c|c|c|c|c|c|c|}
\hline $\begin{array}{c}\text { Year } \\
\text { Godina }\end{array}$ & $\begin{array}{c}\text { Croatia } \\
\text { Hrvatska }\end{array}$ & $\begin{array}{c}\text { Serbia } \\
\text { Srbija }\end{array}$ & $\begin{array}{c}\text { Greece } \\
\text { Grčka }\end{array}$ & $\begin{array}{c}\text { Kosovo } \\
\text { Kosovo }\end{array}$ & $\begin{array}{c}\text { Slovenia } \\
\text { Slovenija }\end{array}$ & $\begin{array}{c}\text { Bosnia \& } \\
\text { Herzego- } \\
\text { vina } \\
\text { Bosna } i \\
\text { Hercego- } \\
\text { vina }\end{array}$ & $\begin{array}{c}\text { Germany } \\
\text { Njemačka }\end{array}$ & $\begin{array}{c}\text { Nether- } \\
\text { lands } \\
\text { Nizozem- } \\
\text { ska }\end{array}$ & $\begin{array}{c}\text { Monte- } \\
\text { negro } \\
\text { Crna } \\
\text { Gora }\end{array}$ & $\begin{array}{c}\text { Norway } \\
\text { Nor- } \\
\text { veška }\end{array}$ \\
\hline 2005 & 684.660 & 1.251 .087 & 739.790 & - & 211.627 & 24.237 & 5.165 & - & - & - \\
\hline 2006 & 1.273 .001 & 1.220 .575 & 865.863 & - & 569.786 & 33.029 & 98.200 & - & - & 106.331 \\
\hline 2007 & 1.754 .899 & 1.648 .005 & 1.145 .094 & - & 623.380 & 150.502 & 236.563 & 1.753 & 136.225 & 194.860 \\
\hline 2008 & 2.571 .370 & 1.943 .611 & 1.484 .073 & - & 793.266 & 398.310 & 127.099 & 1.282 & 182.061 & 245.792 \\
\hline 2009 & 2.036 .208 & 1.068 .783 & 1.084 .594 & 777.846 & 902.274 & 255.788 & 38.021 & 39.185 & 296.039 & 197.830 \\
\hline 2010 & 1.110 .764 & 683.513 & 673.697 & 1.293 .433 & 467.050 & 401.424 & 65.245 & 312.169 & 165.598 & 23.278 \\
\hline 2011 & 1.109 .243 & 717.848 & 636.615 & 1.383 .704 & 463.558 & 396.575 & 504.836 & 188.487 & 153.522 & 139.483 \\
\hline 2012 & 1.209 .687 & 927.161 & 228.138 & 1.493 .620 & 719.450 & 381.917 & 305.729 & 359.594 & 273.539 & - \\
\hline 2013 & 1.382 .164 & 797.617 & 105.953 & 1.636 .708 & 734.543 & 277.835 & 411.337 & 435.649 & 111.531 & 2.466 \\
\hline $\begin{array}{c}\text { Total } \\
\text { EUR }\end{array}$ & 13.131 .996 & 10.258 .201 & 6.963 .818 & 6.585 .311 & 5.484 .933 & 2.319 .617 & 1.792 .195 & 1.338 .119 & 1.318 .514 & 910.041 \\
\hline$\%$ & $24 \%$ & $19 \%$ & $13 \%$ & $12 \%$ & $10 \%$ & $4 \%$ & $3 \%$ & $2 \%$ & $2 \%$ & $2 \%$ \\
\hline Mean & 1.459 .111 & 1.139 .800 & 773.758 & 731.701 & 609.437 & 257.735 & 199.133 & 148.680 & 146.502 & 101.116 \\
\hline Std Dev & 570.520 & 429.663 & 436.059 & 731.769 & 208.829 & 154.930 & 176.115 & 178.418 & 102.733 & 97.987 \\
\hline $\begin{array}{c}\text { Coef } \\
\text { Var }\end{array}$ & $39 \%$ & $38 \%$ & $56 \%$ & $100 \%$ & $34 \%$ & $60 \%$ & $88 \%$ & $120 \%$ & $70 \%$ & $97 \%$ \\
\hline AROC & $9 \%$ & $-5 \%$ & $-22 \%$ & $20 \%$ & $17 \%$ & $36 \%$ & $73 \%$ & $151 \%$ & $-3 \%$ & $-42 \%$ \\
\hline$r$ (Corr.) & -0.0121 & -0.6177 & -0.6569 & 0.9411 & 0.4141 & 0.7531 & 0.7055 & 0.8969 & 0.5709 & -0.2992 \\
\hline
\end{tabular}




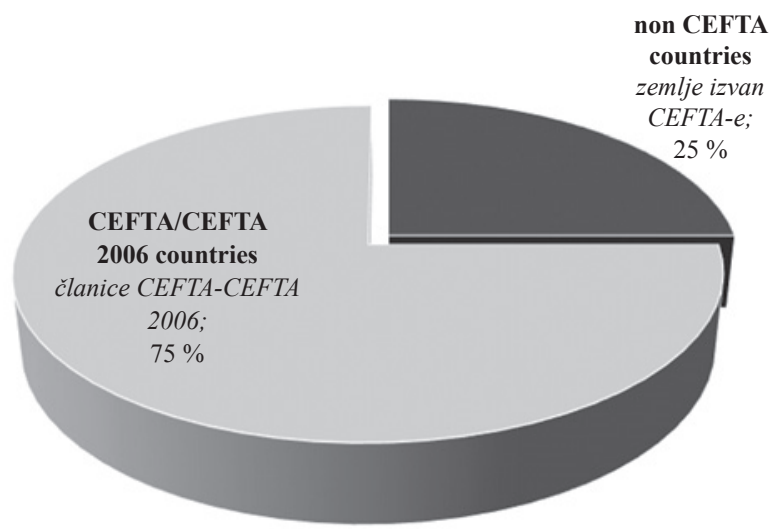

Figure 8 Total export of furniture from Macedonia to CEFTA and non CEFTA countries for the period 2005-2013 Slika 8. Ukupni izvoz namještaja Republike Makedonije u zemlje članice CEFTA-e i zemlje izvan CEFTA-e zarazdoblje od 2005. do 2013.

bia with a share of about 19 percent of the total export, and then Greece with about 13 percent and Kosovo with about 12 percent.

When the rates of change in successive time periods are approximately equal, and assuming that the average rate of change will not change, it would be possible to predict variable values in future periods. Based on the average rate of change for export $(10 \%)$ of furniture from Macedonia in the observed period, prediction model for future values of export were developed. Correlation analysis was used to determine the correlation level between the values of export as dependent variable and time as independent variable. Pearon's linear correlation coeficient $r$-which describes the direction and strength of correlation relationships, was positive $r=0.5101$, but not very high and close to 1 , which shows that the predicted trend line presented in Graph 1 of this research is not reliable.

Furthermore, export of wood furniture from the Republic of Macedonia is different for different categories and influences the total export. It can be concluded that Macedonian wood furniture manufacturers use CEFTA 2006, but not enough. The reason is a great number of small manufactures, investment in serial production and newer and modern machinery and low buying power of customers on the market, which all result in lower export. This situation has to be changed if wood furniture companies intend to be more competitive and ready for the global market.

\section{CONCLUSION}

\section{ZAKLJUČAK}

It is a generally accepted fact that socioeconomic development greatly depends on investment, and therefore long-term development can only be achieved through investment, because well targeted investment activity is the primary assumption for all aspects of competitiveness (Ojurović et al., 2013). In recent decades, the furniture industry has gone through major changes. The life cycles of products are becoming in- creasingly shorter, leading to an increasing need for intensified development of new products or updating the existing ones. At the same time it is necessary to continually update the technology and equipment as well as to include developmental and research activities, education and the search for financial resources for the development and business operation of companies (Berginc et al., 2011).

CEFTA 2006 is an exceptionally important step in the trade cooperation and integration of the region. Based on trade liberalization, from 2009 furniture trade in CEFTA countries is free of custom duties. This preferential treatment is a very important facilitator for higher export from the Republic of Macedonia to the CEFTA market.

Regarding the export of six categories of wood furniture from the Republic of Macedonia in the period 2005-2013 to CEFTA/CEFTA 2006 countries: the export of office wood furniture accounts for 64 percent, export of kitchen wood furniture accounts for 78 percent, export of bedroom wood furniture accounts for 91 percent, export of dining and living wood furniture accounts for 70 percent, export of shop wood furniture accounts for 49 percent and export of other wood furniture accounts for 59 percent of the total export.

According to preliminary statistical data for the period 2005-2013, Macedonian wood furniture industry achieved an export of EUR 39,098,000 to CEFTA/ CEFTA 2006 countries and a share of 75 percent in the total export. It can be concluded that the countries in the region, especially CEFTA/CEFTA 2006 countries, will be the strategic markets for Macedonian export of wooden furniture in the future. Preferential conditions specified in the CEFTA agreement and knowledge of the market based on experience gained in the former Yugoslavia is a solid basis for Macedonian furniture manufacturing companies to build their own competitiveness first on the CEFTA market and then also on the European and global market.

\section{REFERENCES}

5. LITERATURA

1. Berginc, J.; Hrovatin, J.; Feltrin, M.; Mächtig, S. J.; Zupančič, A.; Oblak, L., 2011: Analysis of cooperation between furniture industry and designers in product development process. Drvna industrija, 62 (2): 129-136.

2. Efremov, K., 2013: Trade Relations within CEFTA - opportunities and barriers, economic Diplomacy as a tool for supporting new export market opportunities, Regional Export Competitiveness - Trade and Services within CEFTA and EU, 29 May 2013, Skopje.

3. Glavonjić, B.; Vlosky, R. P.; Borlea, G. F.; Petrović, S.; Sretenović, P., 2009: The Wood Products Industry in the Western Balkan Region, October 2009.

4. Kitek Kuzman, M.; Motik, D.; Bičanić, K.; Vlosky, R. P.; Oblak, L., 2012: A comparative analysis of consumer attitudes on the use of wood products in Slovenia and Croatia. Drvna industrija, 63 (2): 71-79.

5. Meloska, Z.; Petrovska, I., 2012: International trade in wood sawn from Republic of Macedonia, paper published in the Conference proceedings from the Interna- 
.... Petrovska, Meloska, Efremov, Postolov: CEFTA Agreement and Opportunities for Wood...

tional Conference WoodEMA 2012 - Wood and Furniture Industry in Times of Change - New Trends and Challenges, Trnava, p. 148-154.

6. Meloska, Z.; Petrovska, I.; Anakiev, B., 2011: Current Conditions and Strategies for Export Strategies of Furniture in the Republic of Macedonia, Proceedings from the International Scientific Conference Development trends in Economics and management in wood processing and Furniture manufacturing, Kozina, Slovenia, June 8th 10th 2011, p. 107-113.

7. Mojsovska, S.; Tosheva, G., 2011: Trade Integration of the SEE Countries within the Region and with the European Union: Complementarities and Effects, International Conference Regional Trade Integration in South East Europe: Benefits and Challenges, December 2011, Skopje, Republic of Macedonia.

8. Oblak, L.; Glavonjić, B., 2014: A Model for the Evaluation of Radio Advertisements for the sale of Timber Products. Drvna industrija, 65 (4): 303-308 http://dx.doi.org/10.5552/drind.2014.1357.

9. Oblak, L.; Zadnik Stirn, L.; Moro, M.; Hrovatin, J.; Mole, S.; Kitek Kuzman, M., 2012: Choice of quantitative method for forecasting of parquet sales. Drvna industrija, 63 (4): 249-254.

10. Ojurović, R.; Moro, M.; Šegotić, K.; Grladinović, T.; Oblak, L., 2013: Analysis of the investment in wood processing and furniture manufacturing entities by key factors of competitiveness. Drvna industrija, 64 (2): 131 $137 \mathrm{http} / / / \mathrm{dx}$. doi.org/10.5552/drind.2013.1235.

11. Petkovska Mirchevska, T.; Petkovska, T.; Majstoroska, J.; Stanceva Gigov, I., 2011: The Influence of the NonPrice Factors of Competitiveness on the Advancement of the Export Offer of the Republic of Macedonia within CEFTA, International Conference Regional Trade Integration in South East Europe: Benefits and Challenges, December 2011, Skopje, Republic of Macedonia.
12. Shumanska, M. S., 2014: Technological development of wood industry enterprises of the Republic of Macedonia, Wood, Design \& Technology, 3 (1).

13. Tosheva, G.; Efremov, K., 2007: Foreign Trade Policy of the Republic of Macedonia in 2006 with focus of CEFTA, Conference for Support the Export of the Republic of Macedonia, 16 April 2007, Skopje.

14. *** 2014: "CEFTA Trade Portal" (online), http://www. ceftatradeportal.com/index.php?option $=$ com_content\&v iew $=$ article $\&$ id $=6 \% 3$ Acefta-trade-portal $\&$ catid $=1 \% 3$ Acefta-portal-mainpage\&lang=en (Accessed Jan. 09, 2015)

15. *** 2014: "CEFTA Secretariat" (online) http://www.cefta.int/ (Accessed Jan. 09, 2015)

16. *** 2014: "Overview on wood industry current trends" (online), Association of Wood-processing Industry and Furniture Manufacturing http://www.mchamber.org.mk/ $\% 28$ S\%28nkxigy55tvx1zc55fgldiw55\%29\%29/default. aspx $? 1 \mathrm{Id}=1 \& \mathrm{mId}=73 \& \mathrm{smId}=9 \& \mathrm{cId}=0 \& \mathrm{pId}=1 \quad$ (Accessed Jan.09, 2015)

17. *** Agreement on the amendment of and accession to the original Central European Free Trade Agreement, Official Gazette of the Republic of Macedonia 69/2007.

\section{Corresponding address:}

Prof. ŽIVKA MELOSKA, Ph.D.

University "Ss Cyril and Methodius"

Faculty of Design and Technology of Furniture and Interior

blvd. Aleksandar Makedonski b, p.o. box 8 1130 Skopje, REPUBLIC OF MACEDONIA e-mail: meloska@fdtme.ukim.edu.mk 